\title{
Advance and Prospect of Technologies on Converter
}

Takatsugu SHIMA

\section{1. 緒}

\section{言}

上吹き酸素転炉法 (LD 転炉) の技術導入は戦後の日 本の鉄鋼生産を革新する上での重要な柱の一つであっ た。この技術は製鋼の生産性の向上とともに鋼材の品質 向上にも大きく作用した。

1957 年の初稼動から 1979 年にいたる約 20 年間の日 本における研究および技術進歩については，日本鉄鋼協 会特別報告書 No. 33 「我が国に扔ける酸素製鋼法の歴 史」1)に詳しく述べられている.

1980 年以降も転炉法に関連して種々の研究, 技術開 発が進んだが, その主なものは, 次のとおりである.

(1)酸素底吹き法を経由して上底複合吹錬法へ展開

(2)溶銑予備処理法との組合せによる高純度鋼, 高清浄 度鋼溶製，およびマンガン鉱石直接使用などによるコス トダウン技術の進展

(3)品質向上およびコストダウンの視点から真空処理技 術を中心とした二次精鍊の普及

(4)計測・制御手段の進歩による, 成分, 温度的中率向 上から自動吹鍊への展開

(5)炉寿命延長, 酎火物原単位の低下

(6)溶融還元やスクラップ溶解などへの機能拡大

本特集号においては，これらについての最近の技術進 歩がまとめられている，さきにあげた「我が国における 酸素製鋼法の歴史」と合わせて, 転炉製鋼技術の発展を まとまった形で把握できる貴重な資料になると思われ る.

本稿では転炉法関連の技術進歩の流れを概観し，今後 の技術進歩の方向を展望してみたい.

\section{2. 発表件数の推移からみた研究・技術開発活動}

LD 転炉技術導入から今日までの約 30 年間の, 転炉 に関連する研究，技術開発の活動のウェイトを反映する ものとして, 日本鉄鋼協会の講演大会および製鋼部会で
の発表件数の推移を調査した.

ここで，「転炉に関連する発表」としてカウントした のは, 転炉の設備, 操業, 計測・制御に関するもののほ かに, 転炉スラグ, 転炉用酎火物関係, 溶銑子備処理 (ただし，脱硫だけを目的とするものは除いた)，および スクラップ溶解, 溶融還元（転炉を用いたものに限定し たである.

図 1 に示した調査結果は次のように読み取ることがで きる.

(1)講演大会発表における発表は 1961 年頃から増え 1966 年に最初のピークを示す. 製鋼部会発表では 1967 年に鋭いピークを示す。これらは各社の LD 転炉工場 の建設の進展と対応している.

(2)そのピークの後, 1974 75 年まで発表件数は減少

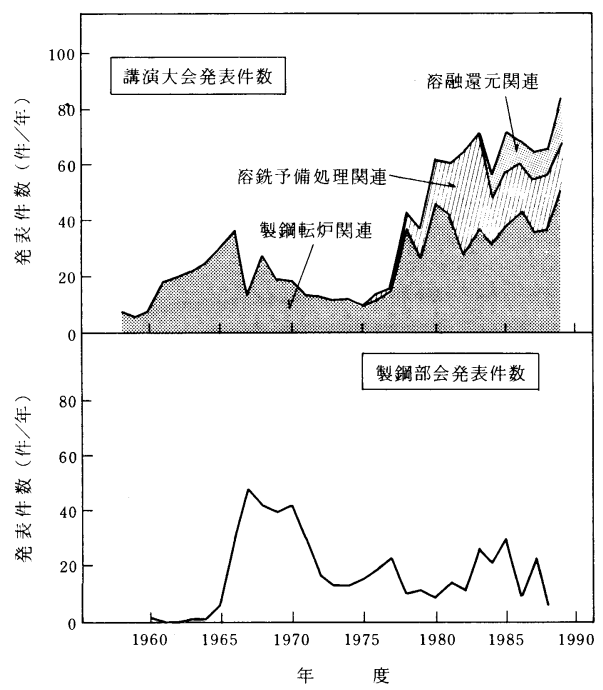

図 1 日本鉄鋼協会講演大会および製鋼部会におけ る転炉関連発表件数の推移

平成 2 年 4 月 23 日受付（Received Apr. 23, 1990）（依頼展望）

* 本会共同研究会製鋼部会長 新日本製鉄(株)取締役，製鋼技術部長（Steelmaking Technical Div., Nippon Steel Corp., 2-6-3 Otemachi Chiyoda-ku, Tokyo 100-71)

Key words : steelmaking ; converter ; combined blowing ; treatment of hot metal ; smelting reduction. 
を続ける。これは，LD 転炉技術で生產が順調に行われ るとともに，次の技術開発の方向が明確ではなく模索の 時期といえよう.

(3)製鋼部会発表件数では 1977 年に小さなピークが認 められる.これは, 当時, 問題になった省エネルギー, 省資源や環境問題に対応寸るための作業改善や転炉スラ グ関連の発表が増えたからである。

(4)講演大会では, 1978 年以降, 全体として発表件数 は増加傾向が続いている。 これは, 溶銑予備処理, つい で複合吹錬（それらは 1980～82 年にピークを示す），さ らに 1985 年以降は溶融還元に関するものが加わったこ とによる。

(5)製鋼部会の方は，1982 85 年頃にピークがみられ る.これは, 講演大会の $1980 \sim 82$ 年のピークに対応し 内容的には溶鉄予備処理と複合吹錬の実用化が中心であ る.

以上のようにこの 30 年間の転炉に関連する研究・技 術開発の活動には, LD 転炉の導入に関連する第 1 の ピーク（1966 67 年）と, 溶銑予備処理, 複合吹錬を中 心とする第 2 のピーク（1980～85 年）が明瞭に認められ る. さらに講演大会の発表件数については 1985 年以降 も高いレベルが維持されている.

このように，転炉に関連する研究・技術開発は現在も 活発な状態にあるが内容的な多元化が見られる。

\section{3. 転炉製鋼法の技術変化}

転炉の本来機能である溶銑精鍊技術については，鋼材 の高級化 (高純度, 高清浄度化) と高品質材の大量処理 技術と大幅コストダウンの要求に応えるために,「精鍊 機能の分化」という方向が取られてきた（図 2 ).

すなわち，「溶銑予備処理一転炉吹錬-取鍋精鍊」とい う方式である.溶銑予備处理（ここでは脱りん）の此率 が $70 \%$ 以上の製鉄所が増えている（図 3 )。また，取鍋 精錬については, 鋼種に応じて各種の処理を行うことが

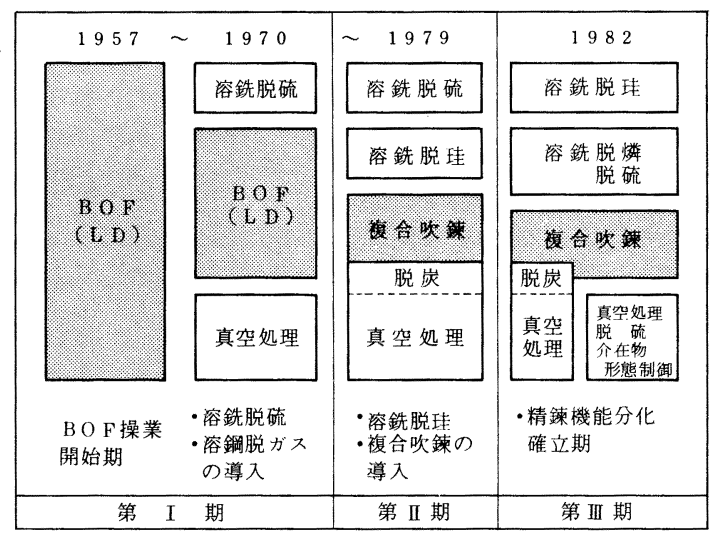

図 2 精錬機能分化の進展

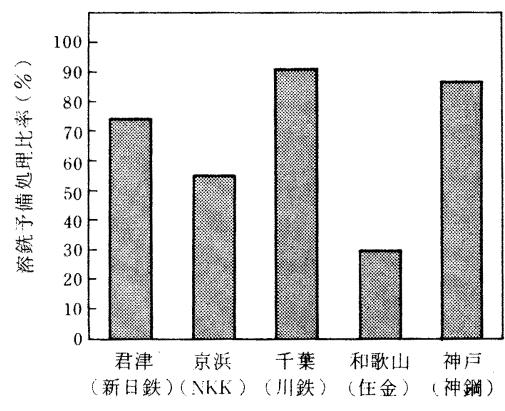

困 3 最近の溶銑子備処理比浨の例

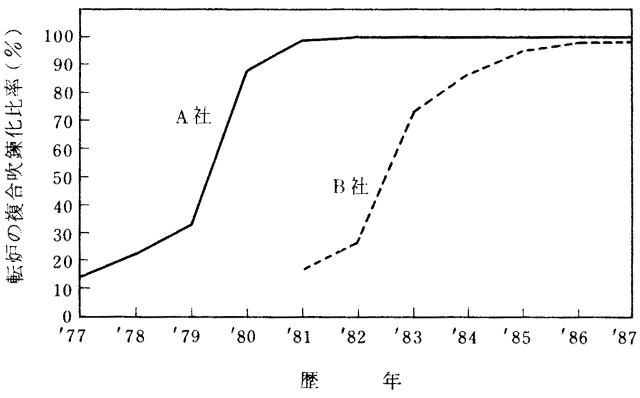

図 4 転炉吹錬の上底吹き化の推移

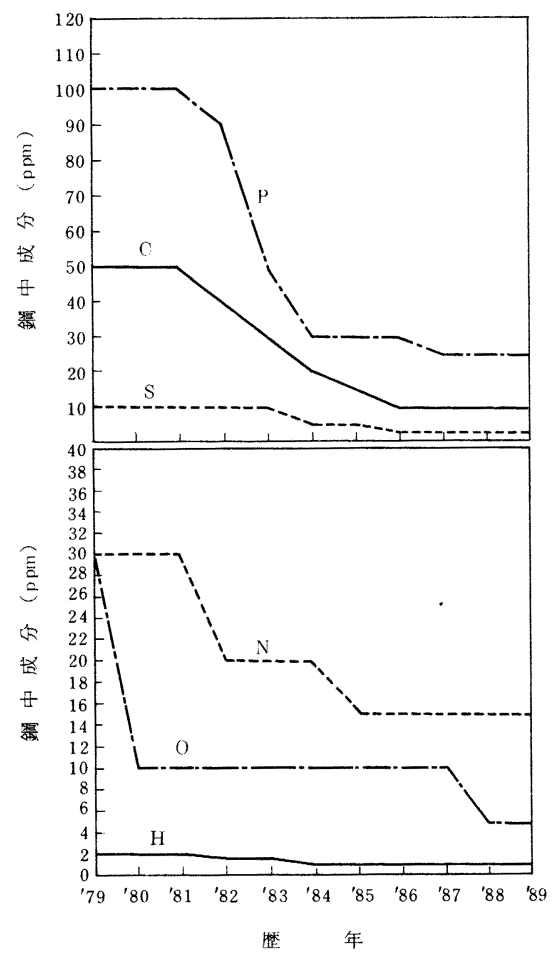

図 5 溶鋼高純度化実績の推移 


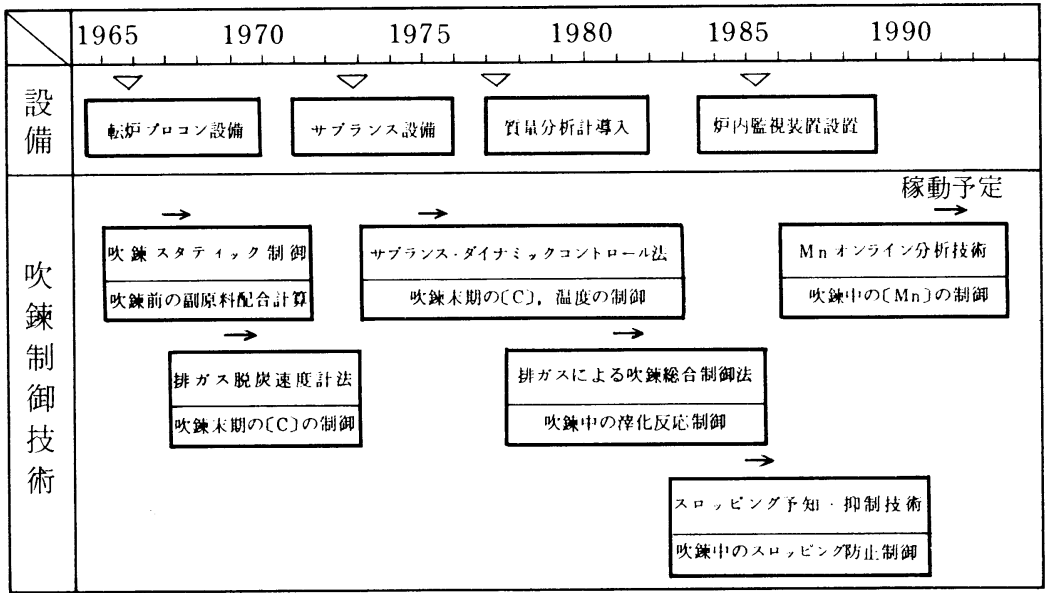

四 6 吹錬制御技術の進展

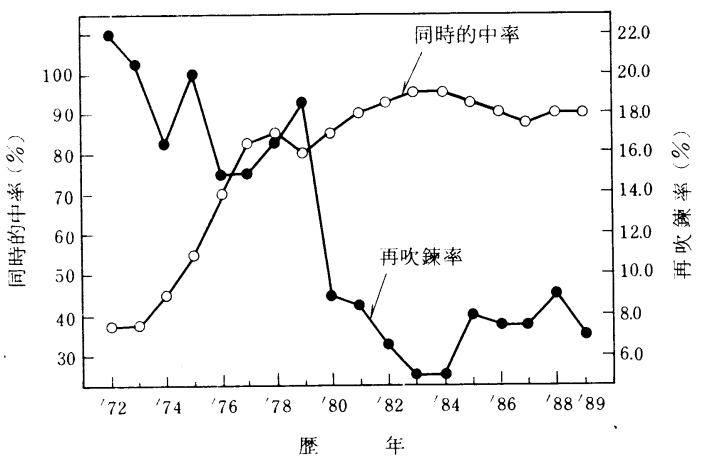

汹 7 吹錬吹此め同時 (成分, 温度) 的中率の推移 (新日鉄 堺)

普通になっている.

吹錬方式については，1979 年以降，急激に上底複合 吹鍊化が進んだ(泪 4 ).

この一つの大きな技術変化を背景に，転炉の技術指標 は次のように変化してきた。

(1)溶鋼の高純度化

転炉吹止:め時点の溶鋼不純物レベル（とくに $\mathrm{P}, \mathrm{S}$, N) は大幅に低下し, 後続の取鍋精錬との組合せで図 5 に示すように，溶鋼の高純度，高清浄度化の進展に大き く奇与することとなった。

(2)成分，温度的中率

底吹き攪找による溶融物の均一化効果に加えて，眓 6 に示すような各種のセンサーの進歩および制御モデルの 開発によって，成分，温度の同時的中率の们上，再吹錬 率の低下が進んだ（㲸７）。

(3)マンガン鉱不の直接使用 (四 8)

従来, マンガン源としてフェロマンガンが用いられて

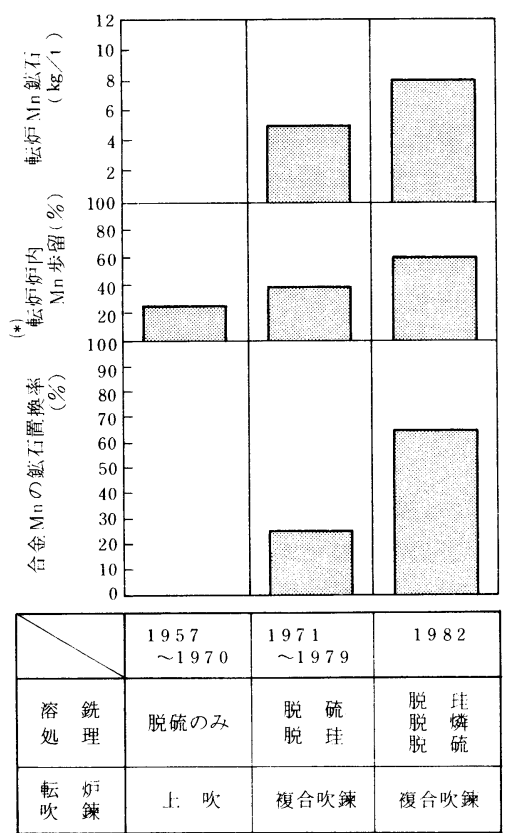

((*)転灯内Mn 歩留は粉台》n 歩留を示す）

図 8 マンガン鉣石使用によるフェロマンガン置換 の推移 (新日鉄 大分)

きたが，溶銑予備処理と転炉底吹き攪拌技術を背景と して，転炉でマンガン鉱石を直接還元することが経済 的な方法となった。現在では転炉におけるマンガン源 の約 $50 \%$ はマンガン鉱石であり, 今後も増加するであ 万う。

(4)耐火物原単位の低減 (図 9 )

耐火物材質の向上（マグカーボンなど），操業技術 


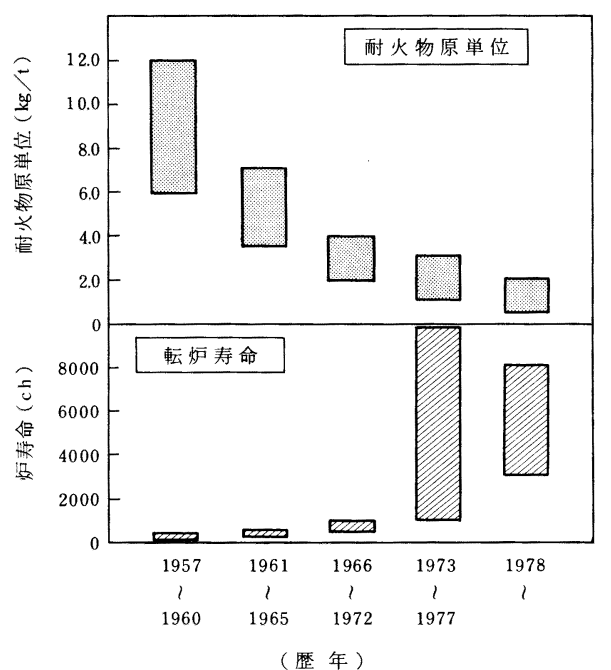

図 9 転炉炉寿命と酎火物原単位の推移

（スラグコーティングなど），熱間補修技術などの組合せ により酎火物原単位は大幅に低下した。また，炉寿命の 延長は吹鍊の安定にも効果がある.

以上のように，前後工程（溶銑予備処理，取鍋精鍊） に機能を分化することによって転炉自体の精錬機能は縮 小されたといえるが，マンガン鉱石の還元のような新た な機能も取り込むことによって転炉製鋼法は，LD 転炉 の操業開始期とは大きく変化している.

\section{4. 技術変化の推進}

今日までの転炉技術の進展を可能にしたのは，次のよ うな技術の思想と手段であると思われる.

(1)溶鋼の穓找を適正条件で行うこと

川鉄の Q-BOP の研究 2 加ら㙕拌効果の重要性が認識 され，それに刺激されて，最適底吹き攪找条件という観 点から上底吹き転炉法が各社で開発されることになっ た.

技術手段のポイントである底吹き羽口技術について は, ガス吹込み量レベル, 安定性㧍よび可変幅, 設備費, 操業の簡便さなどを考慮して, 各種の方法が開発され $た^{3)}$.

(2)個々の精錬反応を最も有利な条件で行えるように分 割精鍊すること

市場の要求により, 高級品質を大量に, しかもコスト ダウンをはかりながら実現させるプロセスの開発が必要 となった，すなわち, 従来, 転炉で行われていた脱珪, 脱りんを予備処理工程に移し，さらに脱珪と脱りんも分 離して行うというものである.

これは，脱りん反応は低温で，かつ $\mathrm{Si}\left(\right.$ および $\left.\mathrm{SiO}_{2}\right)$ が高くない状態で行った方が有利という治金原理に基づ
いている.

なお，溶銑予備処理の研究は，高純鋼溶製とともに， フラックスを精錬機能が高い状態で使用することに よって，製鋼スラグ生成量を減少することも目標として いた.

この分割精錬を支える技術としては，大量の粉体をイ ンジェクションする技術, 上底吹き転炉で得た羽口技術, 混銑車用や取鍋用の耐火物技術などがある。

(3)転炉での熱的余裕度を確保すること

溶銑予備処理によって低下した転炉の熱的余裕度を補 い,さらにスクラップの溶解量を増やすために, 転炉で の発熱量増加技術が注目されることになった.

その手段としては炉内二次燃焼率増加と炭材添加の二 つがある。

前者については，二次燃焼率を上げることによって耐 火物原単位が増加する問題が残されており，広く実用化 されるにはその解決が望まれている.

後者については, 全量スクラップ溶解も可能になって いるが，不純物の点からどのような炭材を選択し，どの ように用いるかによって種々の方式が開発されている.

(4)転炉内で酸化物の還元能を高めること

底吹きガス攪拌によってスラグの過酸化度が小さく なったことにより，スラグ内の有価成分を炭素で還元回 収できる可能性が開けた。

それを経済的に行うための手段として，次の二つの方 法がある.

a ) スラグ量が少ないことを利用する方法

予備処理溶銑を用いて転炉でマンガン鉱石の還元回収 を行うのに用いられている. $(\mathrm{Mn}) /[\mathrm{Mn}]$ 分配比を低く できなくてもスラグ量が少なければスラグへのマンガン ロスが抑制できることを利用している.

この場合, 分配比自体は低くないのでメタル浴の成分 濃度が高くなると, 酸化物ロスの絶対值が増える。ちな みに転炉出鋼時の $[\mathrm{Mn}]$ として約 $1.5 \%$ の值が得られて いる.

b ）スラグ量が多いことを利用する方法

「スラグ量を増やすことによって攪找状態のメタル浴 と酸素ジェットを遮断し，スラグ還元の進行とスラグの 酸化物の還元反応の両立を可能にする」という原理が フェロクロム溶融還元研究で見いだされた ${ }^{4)}$ 。なお，多 量スラグ (例えば約 $1 \mathrm{t} / \mathrm{t}$-metal) をスロッピングさせ ないで安定保持することは, 炭材を共存させるという方 法で可能になった5).

この方法では, 成分分配比を小さくできるので, メ夕 ル内成分濃度が高くなっても回収歩留りが低下しないと いう特徴がある．例えば，フェロクロム溶融還元では ( T. Cr) $/[\mathrm{Cr}]=0.5 / 55^{4)}$, フェロマンガン溶融還元で は $(\mathrm{T} . \mathrm{Mn}) /[\mathrm{Mn}]=5 / 65^{6)}$ の実験值が得られている. 


\section{5. 今後の展 望}

溶銑を原料とする転炉製鋼法については，「溶銑予備 処理一上底吹き転炉-取鍋精錬」の組合せによる高純度 鋼, 高清浄度鋼の大量生産方式が確立しているが, 次の 3 点については今後も技術開発を続けてゆく必要があろ ).

(1)分割精錬の理想とする機能の追及

精錬機能を分割して，個々の精錬反応を最も有利な条 件で行えるようにすれば，反応効率が向上し生成スラグ 量も減少するはずである。しかし，現時点では，分割精 鍊は溶鋼高純度化には効果があるが，反応効率は狙った レベルに達しているとは言えず, 十分に本来機能を発揮 しているとは言い難い状態である.

高純度鋼の要求はますますきびしくなっている現状を 踏まえ,「精錬効率の極限追及」という観点から分割精 鍊法のいっそうの機能向上を図る必要がある.

(2)自動吹錬などによる省力化の極限追及

(3)上記 2 項目を実現した上での精鍊工程のシンプル化 精錬の機能分化は個々の反応の制御に有利であるが, 全体としては極力，工程数が少ない方が望ましい.すで に方向が定まっている高純化と自動化の方向と矛盾する ことなく，また分割精鍊の結果得られた品質を維持しつ つ工程をシンプル化する方向を指向することは今後の重 要課題になると思われる.

一方, 鉄源の多様化に対応する方策としては「熱的余 裕度確保, 還元機能の追及と実用化」を進めてゆく必要 がある。

最近, スクラップ発生量増加, 溶融還元法研究の進展 など, 鉄源がこれまでの溶銑中心の状態から徐々にでは あるが多様化してゆく傾向が見られる.

スクラップ溶解法, 溶融還元法としては種々の方式が ある中で，転炉を利用する方式は，複合吹錬転炉での熱 的余裕度確保, 還元機能増加の技術開発を踏まえて, 実 用技術として適用対象の拡大が進むと予想される。すな わち，転炉技術が鉄源フレキシブル化技術の中核になっ てゆくことが期待できる.

\section{6. ま と め}

約 30 年前に技術導入された酸素上吹き転炉法 (LD 法）は，精錬の機能分化と上底吹き複合吹鍊の技術を取 り入れて変化し, 現在, 「溶銑予備処理-転炉複合吹錬取鍋精鍊」の組合せからなる方式が，コストダウンを実 現しつつ, 高純度・高清浄度鋼を含む溶鋼の製造法とし て広く実用されはじめている.

今後の研究開発課題としては,

(1)分割精錬の特色を完全に発揮して，プロセスとして の対応力を増し, 諸条件が厳しくなる中で生産性, 品質, コスト各面でいっそうの向上をなすこと

(2)高純化，自動化という方向を満足しつつ，分割され た精錬反応を再配列して極力単純化したプロセスに組み 立て直すこと

などがあげられる.

一方，上底吹き転炉の機能拡大として開発されてきた 熱的余裕度確保，還元機能増加を利用した溶融還元やス クラップ溶解技術は, 今後, 鉄源フレキシブル化技術と して実用が進むことが予想される.

現在，転炉に関連する研究・技術開発の活動は，鉄鋼 協会の講演大会や製鋼部会の発表件数に見られるよう に，高いレベルにある.

すでに方向が見えてきているもの以外にも，転炉に新 しい技術手段を導入することによって，転炬技術のいっ そうの深まりと広がりが押し進められることを期待した w.

\section{文献}

1）日本鉄鋼協会特別報告書 No. 33 「我が国における酸素製 鋼法の歴史」(日本鉄鋼協会編）（1981）

2 ) 斎藤健志, 中西恭二, 加藤嘉英, 野崎 努, 江見俊彦: 鉄と鋼, 68 (1982), A41

3 ) 半明正之: 第 100·101 回西山記念技術講座 (日本鉄鋼協会 編) (1984), p. 201

4 ) 藤田正樹, 片山裕之, 桑原正年, 斎藤 力, 石川英毅, 梶岡博幸: 鉄と鋼, 74 (1988), p. 680

5 ) 平田 浩, 松尾立高, 片山裕之, 石川英毅, 梶岡博幸: 材料とプロセス, 2 (1989), p. 173

6 ) 藤田正樹, 片山裕之, 石川英毅, 梶岡博幸: 鉄と鋼, 74 (1988), p. 801 